\title{
Rethinking Principles of School Mathematics during the COVID-19 Pandemic: A Multiple-Case Study on Higher Education Courses Related to Teaching Mathematics
}

\author{
Aysenur Yilmaz ${ }^{1 \star} \mathbb{C}$, Merve Kostur ${ }^{2}(\mathbb{C}$ \\ ${ }^{1}$ Mathematics and Science Education Department, Faculty of Education, Kahramanmaras Sutcu Imam Unıversıty, Kahramanmaras, TURKEY \\ ${ }^{2}$ Mathematics and Science Education Department, Faculty of Education, Baskent University, Ankara, TURKEY \\ *Corresponding Author: aysenuryilmaz@ksu.edu.tr
}

Citation: Yilmaz, A., \& Kostur, M. (2021). Rethinking Principles of School Mathematics during the COVID-19 Pandemic: A Multiple-Case Study on Higher Education Courses Related to Teaching Mathematics. International Electronic Journal of Mathematics Education, 16(3), em0653. https://doi.org/10.29333/iejme/11103

\section{ARTICLE INFO}

Received: 27 Dec. 2020

Accepted: 9 Jun. 2021

\begin{abstract}
The study was carried out with prospective teachers (PTs) in Primary School Teaching Program in a private university ( $n=43)$ and Middle School Mathematics Teaching program in a public university $(n=46)$. In this paper, multiple-case study was adopted to explore PTs' opinions and to reveal the differences between two universities in terms of taking a mathematics education course through online teaching when the COVID-19 pandemic was very first appeared. The content of the course was based on the principles of school mathematics which were put forth by National Council of Teachers of Mathematics [NCTM]. Hence, the principles were used as the themes in the data analysis. For this purpose, a survey was used to explore the advantages and the challenges faced in online teaching from the PTs' perspective. The analysis of the data showed that the PTs at both universities had both positive and opposing views towards online mathematics education course as mandated by the pandemic. Besides, the technology principle in NCTM was found to be a principle in which the other principles were organized and applied according to it. PTs' reflections on the learning and teaching principles in practice were at the forefront. The reflections regarding the assessment and the equity principle were not among the principles that were frequently mentioned. Discussion on and suggestions for overcoming the challenges were elaborated on.
\end{abstract}

Keywords: COVID-19 pandemic, online teaching, NCTM principles, higher education, case study

\section{INTRODUCTION}

The recent COVID-19 pandemic has led to massive changes in teaching practices in education system due to far-reaching restrictions posed by the current situation. This inherently produced some challenges for both instructors and learners in the transition period from the conventional to remote teaching in Turkey. In the shift from face-to-face education to online teaching, digital awareness attained an immense prominence. Teachers' and learners' levels of digital literacy and competences were expected to be higher in the pandemic. Since the stakeholders were caught unprepared in a relatively short transition period due to the unforeseen pandemic, they were immediately required to face the challenges related to digital technology within a short time span.

On March 11, 2020, World Health Organization [WHO] declared a pandemic for COVID-19 (WHO, 2020). Following this news, some universities in Turkey underwent remarkable changes such as giving a break for higher education, transferring face-to-face education to remote education, or adopting significant amendments in their academic calendars (Eren, 2020). On March 13, 2020 when Turkish Council of Higher Education [CoHE] announced that they suspended education for three weeks starting from March 16, 2020 (CoHE, 2020a), there was a three-week break for classes, and all the higher education institutions were locally closed down. In those days, the mathematics education courses were already completed five weeks of the content. The hopes for faceto-face education were dashed on March 18, 2020 with the announcement that the universities having digital opportunities should start online teaching on March 23, 2020 (CoHE, 2020b). Both universities' presidency offices, the universities focused on in this current study, announced that all the courses except for requiring application would be carried out through online teaching until the end of the 2019-2020 spring semester in accordance with the regulations of CoHE.

The presidency offices of the universities offered instructors two options as synchronous or asynchronous transmission of digital content on the university distance education platform. The instructors of the mathematics education courses structured the online courses as synchronous, for they believed that synchronous transmission of the content would give them more 
opportunities to make a live communication rather similar to previous conventional physical classrooms. Distance Education Application and Research Centers were available at both universities as in most of the other universities in Turkey. Those centers directed the online teaching process after the announcement of pandemic in the spring semester of 2020. They provided instructors and students with digital support to remedy any challenges in the process. They primarily supplied the academics and students with a portal called Moodle, a supportive online portal for face-to-face undergraduate and graduate programs. Some of those centers also equipped interface for online undergraduate and graduate programs. Both universities' administrations provided "technical support" to instructors and students about digital tools and applications needed for online teaching. They also created digital platforms mediated with announcements, regulations, guides, and other necessary information. The details of online teaching system and support videos related to problems were shared on the distance education platforms. The digital platforms utilized for the online courses were different at the universities. The private university provided lecturers with "Adobe Connect" platform for one hour per week while "Zoom" platform was used for the remainingthree course hours every week. The public university, on the other hand, recommended "Zoom" for onlinelessons as well as an online platform called "ALMS". Since Zoom opened up more opportunities for the duration of the course and produced less technical problems during the sessions, it was preferredas a better tool for online teaching. Both instructors had laptops as an equipment of the course. Duration of the courses was four hours every week, and course assessments were depended on the regulations of the CoHE (2020c). Accordingly, the private university preferred online exam and assignments for assessment while the public university evaluated the course outcome through assignments only.

In the faculties of education in Turkey, one of the departmental courses offered in the programs of Primary School Teaching Program and Middle School Mathematics Teaching Education focuses on mathematics teaching, which aims to improve PTs' competences in such domains as pedagogical knowledge, mathematics content knowledge, technological knowledge, and the ability to integrate them. The mathematics education course correlates with many other courses, and PTsare expected to integrate their knowledge of mathematics content, pedagogy, and technology while preparing tasks and lesson plans within the requirements of this course. Therefore, the mathematics education course provides a fertile ground to investigate PTs' views about the effect of emergency online teaching. This course is a mustcourse that is a continuation of the Mathematics Education I which is offered in the first semester of the $3^{\text {rd }}$ grade program. Since user satisfaction is one of the main factors that shows the effectiveness of online education (Roca et al., 2006), identifying PTs' satisfaction and challenges in this online mathematics course will contribute to the practitioners on how future online courses should be shaped.

A key aspect of organizing mathematics education courses covers the National Council of Teachers of Mathematics' (NCTM) six principles of mathematics education, namely Equity, Curriculum, Teaching, Learning, Assessment, and Technology (NCTM, 2000). NCTM's principles are defined as the general rules that could be applied in mathematics education (Filiz \& Ergan, 2020). Although NCTM is a national organization of the United States of America, its principles are widely acknowledgedand integrated into mathematics curricula worldwide. The general structure of the Turkish mathematics curriculum comprises similar aims with NCTM's principles (Filiz \& Ergan, 2020; Umay et al., 2006; Üredi \& Ulum, 2019). To be more specific, the content of the learning areas and the skills are highly similar to NCTM's principles. However, in some aspects, the Turkish mathematics curriculum falls behind NCTM's principles (Umay et al., 2006). Therefore, in the present study, the content of the mathematics education course was built both upon the Turkish mathematics curriculum and NCTM's content, principles, and standards.

The pandemic process has required the instructors to rethink how PTs in online teaching environment will gain the skills that the principles for mathematics education refer to. The abrupt transition to online teaching as well as the lack of experience of both the instructors and the PTs in remote teaching and digital technology have made the reorganization and adaptation processes rather challenging. Educators have to make necessary applications in which technology is integrated into pedagogy for effective teaching and learning (Koehler \& Mishra, 2005; Perienen, 2020) since technology has attained a prominent role in education during the pandemic. Within this respect, understanding what PTs lack in online education is critical to lead researchers and educators to develop programs suitable for online teaching in teacher education.

Research highlights that further studies should focus on the process how students attain learning outcomes and develop their content knowledge, and educators, in return, should explore useful means of achieving a successful teaching, i.e., integrating online technologies into teaching (Baran et al., 2011). It highlights further that such studies should be field-specific (Baran et al., 2011) because each and every discipline has a different working mechanism. A successful technique or teaching method employed in an online course may not produce the same effect for another discipline. Mathematics courses, in that respect, are quite suitable for videoconferencing and the use of multiple representations such as diagrams and graphs, because such technologies facilitate and support learners' motivation and attention, foster interactions, and enhance problem solving and effective learning (Harman \& Dorman, 1998). Considering the specific needs for mathematics teaching, it appears that conducting a study examining the interplay between mathematics teaching and online teaching would be quite telling. Identifying the problems in emergent online teaching courses in teacher training programs, as this study aimed, will not only contribute to the existing research on mathematics teaching but also yield significant results for improving mathematics teacher training programs and online mathematics courses.

It goes without saying that online education brings some problematic aspects with itself, but it also offers some advantages. Regardless of economic status, each and every student should have the right to get equal access to education, and to have equal opportunities and support in education (Devlin \& McKay, 2016; Rose \& Blomeyer, 2007). And online teaching, to a certain extent, provides such an opportunity to reach the masses. Many studies have been conducted and many developmentshave been introduced to provide online education support to socio-economically disadvantaged students (Lambert, 2020). However, it is also well known that some shortcomings of online learning lead to inequalities among students. In emergent online education implemented during the pandemic, the Internet connection and computer hardware have been thought to be the major factors affecting the education process (i.e., Dutta \& Smita, 2020; Karadağ \& Yücel, 2020; Mailizar et al., 2020; Yolcu, 2020). It has been 


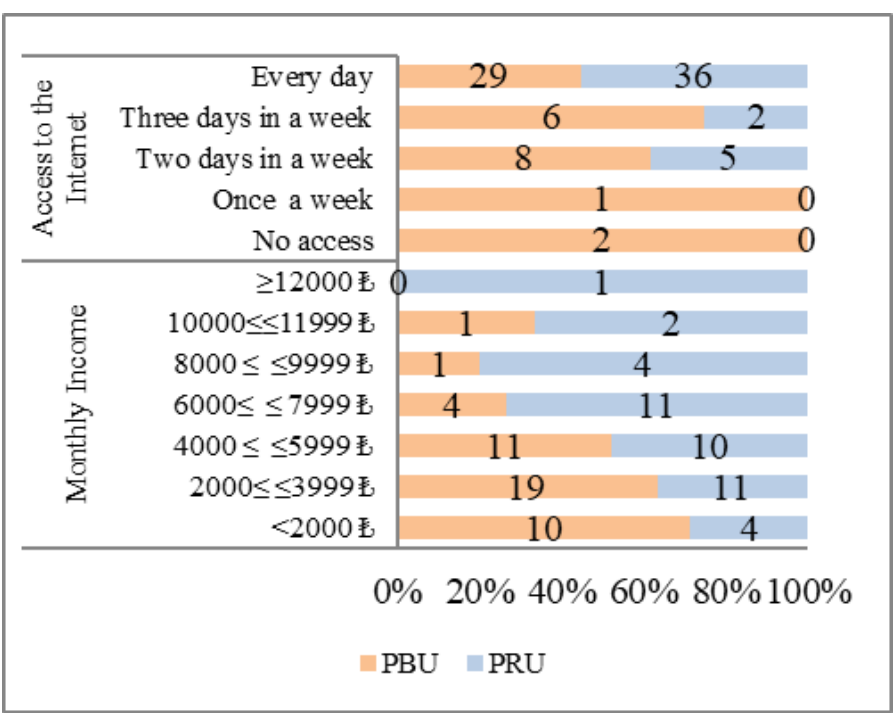

Figure 1. The distribution of monthly income and access to the Internet

observed that economic diversity creates inequality in students' access to resources, which, in effect, creates gaps in opportunities for students to participate in online education. Informed by this aspect of online learning, the present study is intended to examine the equity principle proposed by NCTM (2000) among the students enrolled in two different universities with different socioeconomic status.

Within this context, the current study aimed to explore and dig deeper into PTs' views on the emergent online teaching process specific to mathematics education course based on the six principles of NCTM in terms of the disparity particular to two different universities - a public and a private university - in Turkey during the COVID-19 pandemic. The results of this study aimed to guide the development of online teacher education programs in specific to mathematics education.

\section{METHOD}

The study aimed at investigating the Turkish PTs' views on taking a mathematics education course through online teaching at a public and a private university according to the six principles of NCTM. To pursue this aim, the following research questions were investigated.

1. What is the nature of Turkish PTs' views about challenges and advantages of taking a mathematics education course through distance education?

2. How do Turkish PTs' views about challenges and advantages of taking a mathematics education course through distance education differ in public and private universities?

This study was conducted with 89 PTs (PTs) at third-grade enrolled in a mathematics education course at two different universities in Turkey. There were 43 PTs in the Primary School Teaching program (referring to K1 - K4) at a private university (PRU) and 46 PTsin the Middle School Mathematics Teaching program (referring to K5 - K8) at a public university (PBU). There were 39 female and 7 male PTs in PBU; 38 female and 5 male PTs in PRU. The number of female students was greater than males in both universities; approximately $\% 85$ and $\% 88$ of the PTs were females in PBU and PRU, respectively. Majority of the PTs were above the age of 20 indicating that, when there was a curfew, the majority of those aged 20 and below werein a suitable age range to go out. 35 out of 46 PTs in PBU and 40 out of 43 PTs in PRU wereover the age of 20. The distribution of success of the students in both universities was similar. The PTs' GPA was graded on a4.0 scaleThe required average was 2.0 for graduation from the programs. There were 9 PTs having GPA below 2.0 in PBU. There wereno PTs having GPA below 2.0 in PRU.

Considering that access to the Internet, the Internet quota, having a device on which online lessons are followed (Dutta \& Smita, 2020; Karadağ \& Yücel, 2020; Mailizar et al., 2020; Yolcu, 2020) and monthly income are related to the equity principle in online education, participants of the study were investigated in terms of these variables. The demographic data about monthly income and access to the Internet was represented in Figure 1.

The participants varied in monthly income of their families andthefrequency of the Internet access. These were represented in Figure 1. Accordingly, there was a left-skewed distribution for monthly income of the PBU PTswhile the distribution of monthly income was normal for the PTsin PRU. The majority of the PTs (63\% of the PBU PTs and 84\% of the PRU PTs) from both universities had access to the Internet every day. The PRU PTs had more opportunity for connecting the Internet than the PTs in PBU. $37 \%$ of the PBU PTs had no Internet access every day while it was only $14 \%$ in the PRU. There were no PT who had no Internet access in the PRU whereas two PTs at the PBU did not have access to the Internet at all.

The facilities such as having appropriate devices to follow the courses, a personal computer, and enough Internet quota to follow the lessons were also examined in order to better understand the physical conditions of the PTs in the online education process. The data regarding the physical conditions were presented in Figure $\mathbf{2}$. 


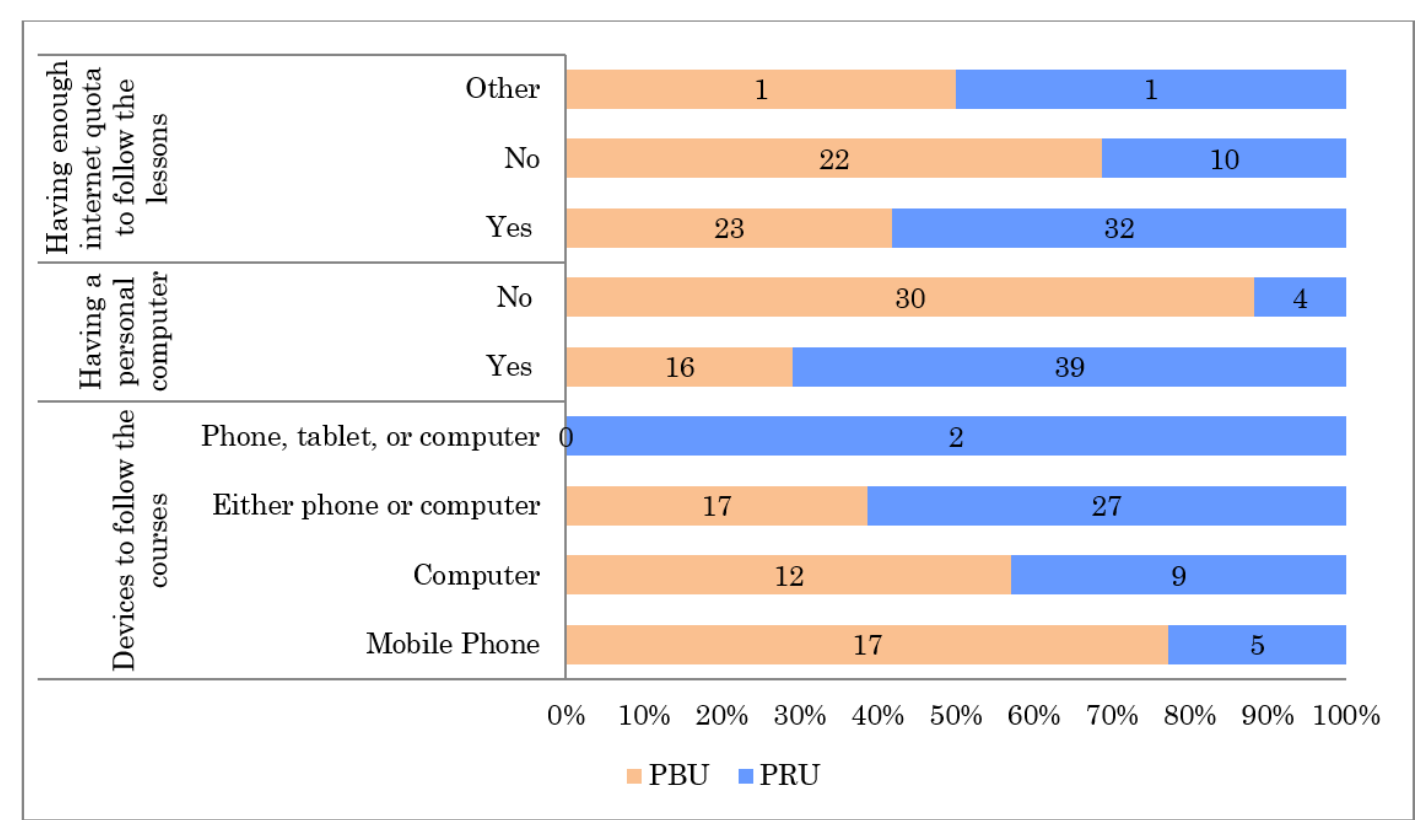

Figure 2. The distribution of physical conditions

As seen in Figure 2, most of the PTs at both universities (37\% of the PBU and 64\% of the PRU) were following the course either on a mobile phone or on a computer. 30 out of 46 PTs (65\%) at the PBU did not own a personal computer while all of the PTs except 4 of them (91\%) at the PRU had computers for their individual use. Half of the PTs in the PBU and about $75 \%$ of the PTs in the PRU had adequate Internet quotas to follow the lessons during the online teaching.

\section{Design of the Study}

This study was designed as a multiple case study (Yin, 2003) focusing on understanding a particular phenomenon i.e., interrogating PTs' opinions about taking a mathematics education course via online teaching in two different contexts, a public and a private university. To go deeper into their experiences in this instant transition to emergency online teaching, the researchers collected the data from the natural context, and the data included verbatim views of the PTs.

Ethics committee approval was obtained for the study. The PTs were informed about the study. They were asked through an online questionnaire, whether they were volunteered to participate in the study. All of the 43 PTs at PRU and 46 out of 48 PTs at PBU were volunteered to participate in the study.

\section{Contexts of the Mathematics Education Course}

The mathematics education course was mandatory for $3^{\text {rd }}$ grade undergraduate students at Primary School Teaching Program and Middle School Mathematics Teaching program at private and public universities, respectively. Before the urgent need for change posed by the pandemic, the implementation of the mathematics education course was quite different. The course had two main objectives specified at the beginning of the academic year. One of them was to be competent about the necessary field knowledge regarding the content of the topicscovered in primary and secondary school mathematics (e.g., numbers and operations, geometry, algebra, measurement, data, and statistics), while the other aimed to be pedagogically capable of how to explain these topics to the students at the appropriate level based on the Turkish Middle School Mathematics Curriculum. Those two main objectives of the course were planned to be achieved in four-hour weekly lessons. Concrete materials related to the aforementioned subjects were also utilized throughout the course and the roles of them were questioned within the activities.

The course was planned on the basis of NCTM principles and the Turkish Middle School Mathematics Curriculum. In the spring semester when the pandemic broke out, the content and the goals of the course remained the same as in the previous years. The goals of the course comprised of the utilization of the six principles of NCTM. The objectivesspecified in the course syllabus included the meaningful application of pedagogy, content, and technology knowledge while teachingthe five learning areas in the Turkish Middle School Mathematics Curriculum. These five learning areas are Numbers and Operations, Algebra, Geometry and Measurement, and Data Processing and Probability (MoNE, 2018). NCTM middle school mathematics learning areas and subject contentare parallel with the Turkish Middle School Mathematics Curriculum (Filiz \& Ergan, 2020; Umay et al., 2006; Üredi \& Ulum, 2019). The mathematics education courses in the two education faculties were planned and implemented in accordance with NCTM principles and standards, having a worldwide acknowledgement, exclusive to mathematics education, and broader in scope than the Turkish Middle School Mathematics Curriculum. The content of the course, in brief, consists of designing activities related to the teaching of mathematics subjects in the five learning areas, making assessment and evaluation, and fostering discussions about teaching mathematics.

\section{Data Collection Tools and Process}

Responses to the survey aided the researchers to answer the research questions. The questions in the survey were fairly essential for improving the course taught remotely and tackled the problems stemming from the implementation of the course 
via an online platform. In an online learning environment, the main purpose of the survey was to identify the learners' needs in order for their better thematic acquisitions. In survey studies, information is collected from a sample by asking questions about learner's characteristic traits, including abilities, opinions, or beliefs (Fraenkel et al., 2011), so such questions constituted the data of the present study. The survey included both close-ended and open-ended questions. The former was directed to obtain descriptive information about the participants such as gender, age, grade, monthly income, the frequency of access to the Internet, the device on which the courses were followed, whether they had their own computers, or had enough Internet quota to follow the lessons. The latter, an open-ended question: 'Are you pleased to take this course through Distance Education? Why?', adapted from Caliskan et al. (2017), was addressed to provide the PTs' opinions of and expectations from the online teaching. The survey was applied to the learners approximately one month after taking courses through online teaching, which enabled the learners to specify learners' needs in online teaching. At the end of the semester after completing the lessons, the same openended question was re-directed to the PTs. The reapplication of the open-ended question provided reflections on whether the initial data were saturated.

\section{Data Analysis}

The PTs' views were evaluated within the scope of the six principles of school mathematics underlined by NCTM, namely the equity, the curriculum, the teaching, the learning, the assessment, and the technology (NCTM, 2000). PTs' responses to the openended question were analyzed within the scope of the principles. The operational definitions of the principles were presented below to make the data analysis process accurate.

Technology, referring to utilizing technology as a tool for teaching and learning, "is essential in teaching and learning mathematics; it influences the mathematics that is taught and enhances students' learning" (NCTM, 2000, p. 24). Technology principle is the centralorganizing principle that affects and changes the other principles due to the nature of the online teaching. With this unexpected transformation caused by the pandemic, the platforms where we taught the lessons, the course materials shared with the PTs, and the assignments evaluating the learning of the content were pushed within the scope of the digital technology. Since remote teaching left the instructors with only one tool; that is, digital platforms, the technology principle, among others, drew the utmost attention sinceit potentially led the implementation of the other principles according to its scope. Before the pandemic and its outcome - the compulsion to exploit digital tools in teaching, this principle was perceived as the integration of technology into the effective teaching and learning processes; however, this viewpoint was changed and should have been changed due to the online teaching, for the learning and teaching processes took place as a digitally-mediated way anymore.

The equity principle was explained as follows: "all students must have the opportunity and adequate support to learn mathematics regardless of personal characteristics, backgrounds, or physical challenges" (NCTM, 2000, p. 12). The equity principle requires instructors to keep their expectations of all students equal. In line with this idea, we, as instructors, had a role of providing our students with the opportunity and necessary support for their learning. In the classroom environment, inequalities would not be visible and they could be treated in a way that avoided other possible inequalities to emerge. However, through online teaching, there emerged digital, social, and physical inequalities regarding the Internet access, the Internet quota, family income, and having personal computer.

The learning principle requires instructors to have a point of view that learning takes place through activating the learner's schemata by "understanding, actively building new knowledge from experience and prior knowledge" (NCTM, 2000, p. 20). In the process of the online teaching, in the present study, this principle was transformed into learning through technology principle. Looking at the learning principle from this perspective, the teaching principle should also be implemented accordingly. In NCTM (2000), it was asserted that "effective mathematics teaching requires understanding what students know and need to learn and then challenging and supporting them to learn it well" (p. 16). The fact that the online teaching action takes place on technological tools indispensable depends on the effective use of this principle and digital technology. To achieve a successful learning process, the assessment principle is inevitable since it enables the instructors to evaluate their instructions and their students' learning processes, which in turn help them make necessary arrangements on their teaching and improve the learner's content knowledge. "When the assessment is an integral part of mathematics instruction, it contributes significantly to students' mathematics learning. It should be an integral part of instruction that informs and guides teachers as they make instructional decisions" (NCTM, 2000, p. 22). The curriculum principle points out that "a curriculum is more than a collection of activities: it must be coherent, focused on important mathematics, and well-articulated across the grades" (NCTM, 2000, p. 14). The curriculum principle, on the other hand, expects teachers to perceive the curriculum as a whole.

The analysis of the data gathered from PTs' written views were analyzed according to NCTM principles which were transformed in a new form considering the emergent online education. The operational definitions of the newly formed principles were given below to express the data analysis accurately.

The learning through technology principle: The answers given by the PTs addressing their own learning with online teaching give an idea to the researchers about the application of the teacher's learning principle; they have been evaluated within the scope of the learning through technology principle.

The teaching through technology principle: The responses of the PTs either positive views showing the needs to be developed about the content and application of the course were evaluated within the scope of the principle of teaching through technology.

Assessment through technology principle: The answers of the PTs that point to the formal or informal assessment and evaluation considering the scope of the course were evaluated within this scope.

Equity through technology principle: When the PTs posed views on the opportunities, individual differences they had or did not have in the emergent online education process, they were evaluated within the scope of the equity through technology principle. 


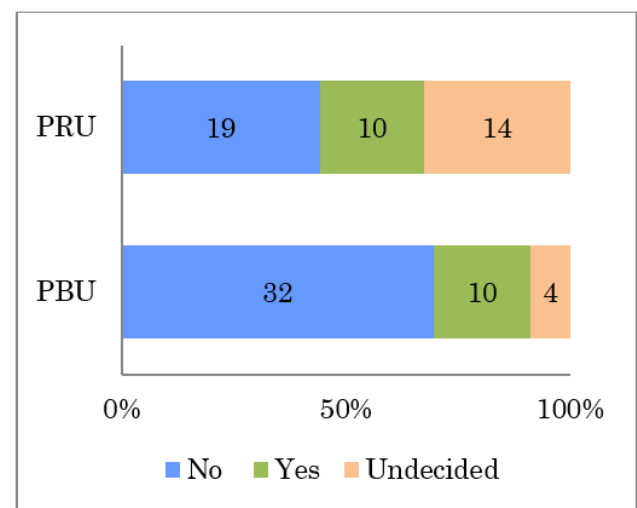

Figure 3. Satisfaction of taking the mathematics education course through online teaching

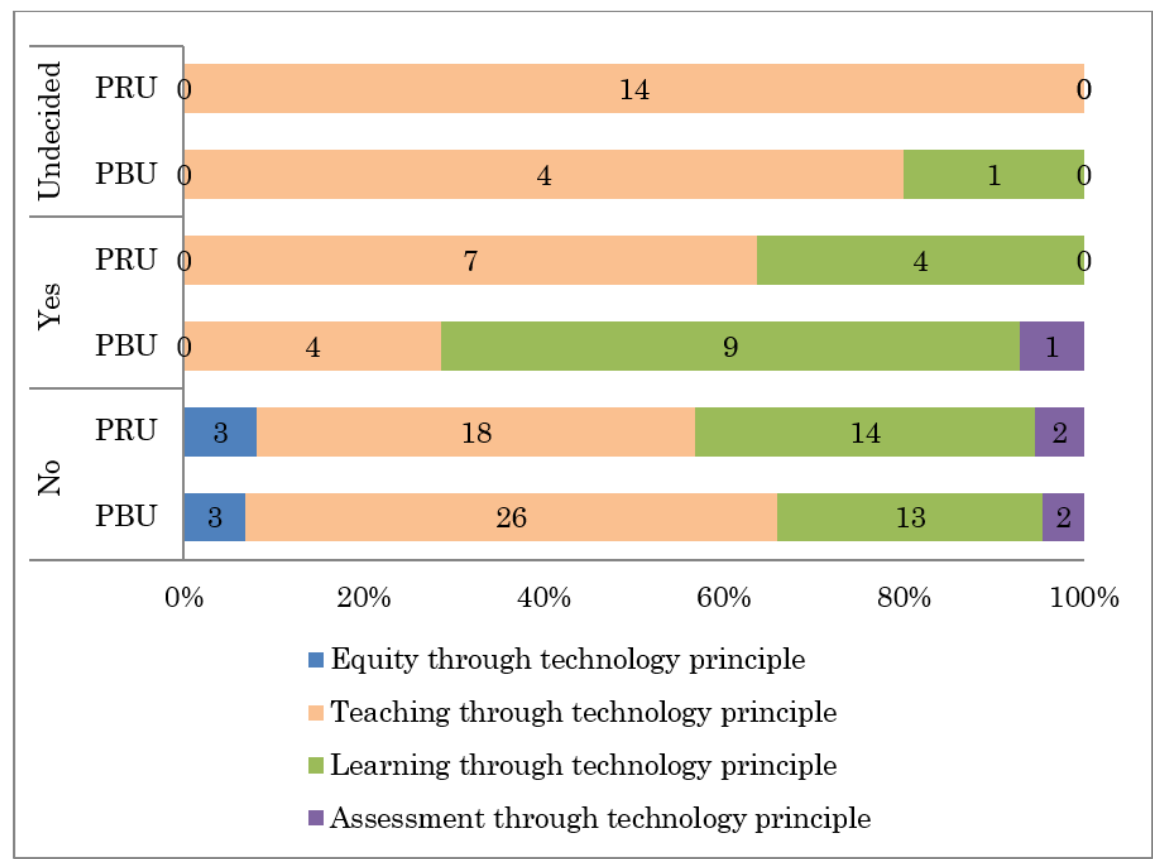

Figure 4. Satisfaction of taking the mathematics education course throughonline teaching regarding the principles

\section{FINDINGS}

The PTs' choices of satisfaction of taking the mathematics education course through online teaching and the reasons of them were presented under the principles for school mathematics by comparing the results obtained fromtwo universities. The reasons were reported as challenges and advantages together with the PTs' sample statements. Frequency of the views (f) about the challenges and the advantages as well as the number of the PTswere also presented.

\section{Choices of Satisfaction of Taking the Courses Through Online Teaching}

The PTs who were satisfied with taking the course highlighted some advantages while those who were dissatisfied stressed some challenges. The PTs who were undecided expressed both advantages and challenges. Figure 3 indicated the general tendency of the PTs in terms of satisfaction addressing the principles. Accordingly, the results of the study showed that most of the PTs were not satisfied about taking this course through online teaching at both universities. On the one hand, at the public university, while $70 \%$ of the PTs (32 PTs) were not satisfied withtaking the course via online teaching, $32 \%$ of them (10 PTs) were satisfied, and $8 \%$ of them (4 PTs) remained undecided. On the other hand, at the private university, $23 \%$ of the PTs (10 PTs) were satisfied with taking the mathematics education course through online teaching while $44 \%$ of them (19 PTs) were not satisfied and $33 \%$ of them (14 PTs) were undecided.

The contents of the PTs' views indicating advantage, disadvantage and indecision were examined and compared with the contents of NCTM's school mathematics principles. The content pointed out by these views of the PTs was evaluated within the scope of the principle which was related to the application of the principle in classroom settings. As represented in Figure 4, PTs from both of the universities were satisfied or dissatisfied with taking the course through online teaching mostly pointed out the ideas about the teaching through technology principle and the learning through technology principle. On the other hand, the undecided PTs mostly presented their views by relating them to the teaching through technology principle. 
Table 1. The views on challenges and advantages of learning principle integrated into technology principle

\begin{tabular}{|c|c|c|c|c|}
\hline & Views & PBU (f) & PRU (f) & PTs' sample statements \\
\hline \multirow{4}{*}{ 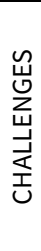 } & Ineffective learning & 8 & 7 & I do not understand the lessons as quickly as we are used to. (PBU25) \\
\hline & Learning environment & 3 & 6 & I learn better in the classroom (PRU7). \\
\hline & $\begin{array}{l}\text { Lack of practice through } \\
\text { concrete materials }\end{array}$ & 1 & - & Lessons, when we used hands-on materials, were more memorable (PBU29). \\
\hline & $\begin{array}{l}\text { Lack of constructing } \\
\text { knowledge }\end{array}$ & 2 & - & $\begin{array}{l}\text { In your courses l've realized a plenty of different approaches and conceptualized } \\
\text { knowledge about mathematics. I think it is a deficiency that we cannot do thisin } \\
\text { online lessons as much as we did in face-to-face lessons (PBU23). }\end{array}$ \\
\hline \multirow{7}{*}{ 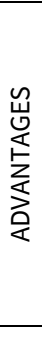 } & Effective learning & - & 2 & Our teacher provides effective learning (PRU21). \\
\hline & Time-saving & 1 & 1 & $\begin{array}{l}\text { Saving more time, it is possible to study PPSE [Public Personnel Selection } \\
\text { Examination, aka. KPSS in Turkish] (PBU46). }\end{array}$ \\
\hline & $\begin{array}{l}\text { Non-theoretical nature of the } \\
\text { course }\end{array}$ & 3 & - & $\begin{array}{l}\text { The course is not only consisted of theories; it is not like a calculus course. I quickly } \\
\text { understand (PBU28). }\end{array}$ \\
\hline & Synchronous teaching & - & 1 & I can learn the content in this platform as same as in the[physical]classroom (PRU22) \\
\hline & Instructor's explanation & 2 & 1 & $\begin{array}{l}\text { Our teacher explains [the topic] at a satisfactory leveland doesn't leave a question } \\
\text { mark in my mind (PBU28). }\end{array}$ \\
\hline & Virtual manipulatives & 2 & - & I think there are better material options on the Internet (PBU2). \\
\hline & Total \# of views & 22 & 18 & \\
\hline
\end{tabular}

In the following, challenges and advantages of taking the course through online teaching were exemplified with the sample PTs' statements. Undecided PTs' views on taking the courses through online teaching were handled following to the title.

\section{Challenges and Advantages of Taking the Course Through Online Teaching}

\section{The learning through technology principle}

The components making the PTs dissatisfied with the online teaching were ineffective learning, learning environment, lack of practice through concrete materials, and lack of constructing knowledge. On the other hand, the components that satisfied the PTs were effective learning, time-saving way of learning, non-theoretical nature of the course, learning through synchronous teaching, instructor's explanations, and the use of virtual manipulatives.

Ineffective learning and learning environment were commonly mentioned drawbacks by the PTs in both of the universities while lack of practice through concrete materials and lack of constructing knowledge were university-specific views on challenges of implementation of the learning principle integrated into technology principle. In terms of advantages of the learning principles, effective learning, virtual manipulatives, synchronous teaching, and non-theoretical nature of the course were university-specific issues while time saving and instructor's explanation were common views addressing the advantages.

There were 16 PTs at PBU (3 PTs stated advantages while 13 PTs referred to disadvantages) and 16 PTs (6 PTs stated advantages while 10 PTs mentioned disadvantages) at PRU addressed the implementation of the learning principle integrated into technology principle. Considering the number of views represented in Table 1, it was determined that some of the PTs in bothuniversities expressed both views, either an advantage or a challenge. In addition to this, in both of the universities, PTs addressed views related to the learning principle integrated into technology principle in a more negative way, as a disadvantage. Based on the frequency of the views, it was observed that the views addressing the disadvantages were related to ineffective learning and learning environment.

\section{The teaching through technologyprinciple}

As represented in Table 2, PTs were dissatisfied with taking the course through online teaching because of limited modeling of fractions, digital exhaustion of remote education, lack of practice through concrete materials, the change in the way of the instruction, lack of real-life meetings, lack of immediate feedback, low level of intrinsic motivation, and lack of communication in the lessons. The PTs expressed their satisfaction of online teaching by referring toeffectiveness of the course, similarity with face-to-face education, non-theoretical nature of the course, synchronous teaching, the attention of the instructor, and enrichment of the content. The common views mentioned by the PTsat both universities were the attention of the lecturers and efficiency of the course. Examining PTs'opinions at PRU manifested that similarity with face-to-face education and synchronous teaching were universityspecific issues.

The PTs' common views about advantages of implementing the teaching principle integrated into technology principle included the attention of the instructor and the effectiveness of the course while the following views represented the common challenges the PTs faced: lack of practice through concrete materials, lack of effective feedback, low level of intrinsic motivation, and lack of communication in the lessons. Examining the PTs opinions manifested that similarity with face-to-face education, nontheoretical nature of the course, synchronous teaching, and enrichment of the content were university-specific issues addressing the advantages of the implementing the teaching principle on online teaching. Limited modeling of fractions, digital exhaustion of distance education, changes of the way of instruction, and lack of real-life meetings produced different results for two universities in terms of challenge.

There were 22 PTs at PBU (4 PTs pointed out the advantages while 18 PTs referred to the challenges) and 16 PTs at PRU addressed the issues (8 PTs mentioned advantages whereas 8 PTs touched upon challenges) related to the teaching principle integrated into teaching principle. Considering the number of views represented in Table 2, some of the PTs in each of the universities expressed their views in both ways, either an advantage or a challenge. In addition to this, at PBU, PTs addressed the 
Table 2. The views on challenges and advantages of teaching principle integrated in technology principle

\begin{tabular}{|c|c|c|c|c|}
\hline & Views & PBU (f) & PRU (f) & PTs' sample statements \\
\hline \multirow{8}{*}{ Challenges } & Limited modeling of fractions & - & 2 & $\begin{array}{l}\text { In one of our lectures we were taught fractions through modeling } \\
\text { and I don't think it was understandable (PRU10). }\end{array}$ \\
\hline & Digital exhaustion of distance education & - & 2 & Our courses are more intense in distance education (PRU28). \\
\hline & Lack of practice through concrete materials & 9 & 4 & $\begin{array}{c}\text { Our teacher used to explain the subject with materials when } \\
\text { necessary and sometimes asked us to use the materials. (PBU14). }\end{array}$ \\
\hline & Change of the way of the instruction & - & 3 & No. Some lectures of our courses had to be changed (PRU5). \\
\hline & Lack of real-life meetings & 2 & - & $\begin{array}{l}\text { I think this course will not be efficient unless [I am] in a classroom } \\
\text { setting with the teacher (PBU40). }\end{array}$ \\
\hline & Lack of effective feedback & 1 & 2 & $\begin{array}{l}\text { When I ask my questions, even if my teacher replies within the same } \\
\text { day, I forget what I think and why (PBU40). }\end{array}$ \\
\hline & Level of intrinsic motivation & 5 & 2 & It is boring because I am listening alone by myself (PRU37). \\
\hline & Lack of communicationin the lessons & 5 & 3 & No mutual interaction (PRU5). \\
\hline \multirow{7}{*}{ Advantages } & Effectiveness of the courses & 1 & 2 & $\begin{array}{l}\text { Yes, I am satisfied. Since the duration of our lessons is long, the } \\
\text { lessons are more detailed (PBU20). }\end{array}$ \\
\hline & Similarity withface-to-face education & - & 1 & $\begin{array}{l}\text { There are not so many big differences between face-to-face and } \\
\text { distance education (PRU14). }\end{array}$ \\
\hline & Non-theoretical nature of the course & 1 & - & $\begin{array}{l}\text { Yes, I am satisfied because this course is not purely theoretical } \\
\text { (PBU34). }\end{array}$ \\
\hline & Synchronous teaching & - & 1 & I am satisfied with the live lessons the instructors did (PRU27). \\
\hline & The attention of the instructor & 1 & 2 & $\begin{array}{l}\text { Yes, I am satisfied.The attention of the instructor is very high } \\
\text { (PRU24). }\end{array}$ \\
\hline & Enrichment of the content & 1 & - & Course content is supported by a variety of sources (PBU11). \\
\hline & Total \# of views & 26 & 24 & \\
\hline
\end{tabular}

Table 3. The views on challenges of equity principle integrated in technology principle

\begin{tabular}{|c|c|c|c|c|}
\hline & Views corresponding to principles & PBU (f) & PRU (f) & PTs' sample statements \\
\hline \multirow{6}{*}{ Challenges } & System-based problems & - & 1 & There are problems in the system (PRU10). \\
\hline & Individual access problems & - & 1 & $\begin{array}{l}\text { Problems such as freezing of the screen occur a lot due to the Internet } \\
\text { (PRU20). }\end{array}$ \\
\hline & Lack of individual resources & 5 & 1 & $\begin{array}{c}\text { No, I am not (satisfied). I do not have the Internet for the online } \\
\text { course platform. (PBU22). }\end{array}$ \\
\hline & Lack of knowledge about onlineeducation & 1 & - & I have a lack of knowledge about distance education (PBU45). \\
\hline & Lack of technological knowledge & 1 & - & $\begin{array}{l}\text { No, it is difficult for me to solve the problems I have with the } \\
\text { computer and the program (PBU12). }\end{array}$ \\
\hline & Total \# of views & 7 & 3 & \\
\hline
\end{tabular}

challenges related to the teaching principle more frequently than the advantages whereas there was a balanced distribution at the PTs' of PRU regarding advantages and challenges. Based on the frequency of the views, the PTs' views from both universities pointing to the implementing the teaching principle tended to be negative, and this often stemmed from the following three challenges: lack of practice through concrete materials, low level of intrinsic motivation, and lack of communication in the lessons.

\section{Equity principle integrated in technology principle}

The PTs' views reflected that the following components related to the equity principle prevented them from being satisfied with taking the mathematics education course remotely: system-based problems (problems arising from the digital platform providing the online meetings), individual access problems, lack of individual resources, lack of knowledge about online education, and lack of technological knowledge. Their views were represented in Table 3.

Lack of individual resources was the common reason stated by the PTs at the PBU and the PRU while the other reasons were university-specific reasons related to this principle. There were 3 PTs (3 PTs stated the disadvantages) at PBU and 3 PTs (3 PTs pointed outthe disadvantages) addressed the issues related to the equity principle integrated into technology principle. Considering the number of views represented in Table 3, the PTs in PBU expressed their views by considering the application of this principle as more than one view related to challenge. The equity principle pointed out by a smallnumber of the PTs but commonly evaluated as a challenge.

\section{The assessment through technology principle}

According to the PTs, assignments and lack of technological knowledge were the challenges while informing about grading was an advantageregarding this principleas presented in Table 4.

It should be noted that each reason was university-specific that PTs in the PBU and PRU focused on different issues related to the assessment principle integrated into technology principle. There were 2 PTs (1 PT pointed out the advantage while1 PT referred to the disadvantage) at PBU and 2 PTs (both of them mentioned the disadvantages) addressed the issues related to the assessment principle integrated into technology principle. Similar to the equity principle, very few PTs made evaluations related to the assessment principle. While those in the PBU emphasized both an advantage and a challenge, those in the PRU just foregrounded the challenging aspect of the assessment principle integrated into technology principle. 
Table 4. The views on challenges and advantages of assessment principle integrated in technology principle

\begin{tabular}{lcccc}
\hline & Views & PBU (f) PRU (f) & PTs' sample statements \\
\hline Challenges & Assignments & 2 & $\begin{array}{c}\text { Even the assignments were in line with the content of the course, I } \\
\text { cannot manage all the other assignments of the other courses } \\
\text { (PRU30). }\end{array}$ \\
\hline Advantages & Informing about the grading & 1 & - & $\begin{array}{c}\text { No, I am not. Because when I send the assignment, I had problems } \\
\text { most of the time about how to send the assignments and whether } \\
\text { they arrived to the teacher (PBU33). }\end{array}$ \\
\hline & Total \# of views & 2 & 2 & $\begin{array}{c}\text { I am not worried about this course because I have been informed } \\
\text { enough and I know exactly what is required from me (PBU11). }\end{array}$ \\
\hline
\end{tabular}

Table 5. The interaction between the reasons for being 'undecided'

\begin{tabular}{|c|c|c|}
\hline Views & $\begin{array}{l}\text { Face-to-faceeducation } \\
\text { environment (f) }\end{array}$ & PTs' sample statements \\
\hline Effective way of instruction & 11 & $\begin{array}{l}\text { No, because the lesson was more effective in face-to-face. Yes, because our teacher } \\
\text { was very nice for including us in the process and enabling us to be active and to learn } \\
\text { actively (PRU15). }\end{array}$ \\
\hline Lack of practice & 1 & $\begin{array}{l}\text { I am satisfied but I would prefer it to be face-to-face because I had the opportunity to } \\
\text { see more different activities since the course was about teaching mathematics (PRU7). }\end{array}$ \\
\hline Lack of communication & 1 & $\begin{array}{l}\text { I do not want to take this lesson from remotely unless we have to; I think it would be } \\
\text { much more beneficial for me to have an eye contact with the teacher(PRU12). }\end{array}$ \\
\hline Intrinsic motivation & 1 & $\begin{array}{l}\text { I do not want to take this lesson from remotely unless we have to.(...) Taking classes } \\
\text { at home is not serious (PRU12). }\end{array}$ \\
\hline Available documents & 1 & $\begin{array}{l}\text { I believe that education should be face-to-face. But I also think that online teaching is } \\
\text { useful for documenting (PBU13). }\end{array}$ \\
\hline Total \# of views & 15 & \\
\hline
\end{tabular}

\section{Undecided PTs' Views of Taking the Courses Through Online Teaching}

The PTs who addressed both advantages and challenges of taking the course through online teaching and those already called themselves undecided were categorized as undecided in this study. Table $\mathbf{5}$ showed that all the undecided PTs compared conventional face-to-face education environment with online education either in positive or negative way by stating five reasons including effective way of instruction, lack of practice, lack of communication, intrinsic motivation, and available documents.

There were 4 PTs at PBU and 14 PTs at PRU who expressed both adverse views. Table 5 demonstrated that all the undecided PTs compared conventional face-to-face education environment with online education either in positive or negative way by giving five different reasons. What was more distinctive among these reasons was that the undecided 11 PTs out of 18 mostly considered the online teaching as effective as face-to-face teaching in terms of participating the learning process actively and receiving the instruction effectively.

\section{DISCUSSION \& CONCLUSION}

Bakker and Wagner (2020) posed a very important question much earlier in the pandemic process: "What are the consequences [of the pandemic] for mathematics education and for research, now and in the future?" (p. 1). As the researchers emphasized, the instructors were suddenly obliged to make instructional decisions to continue educational activities. They pointed out that it was a process during which both those who had and did not have opportunities such as the Internet access and necessary equipment faced enormous challenges. The sudden change in this way led to the use of pedagogies that were not really desirable. As a response to Bakker and Wagner (2020), this study actually paid minute attention to how this sudden change was interpreted by the PTs. In line with this, as suggestions for the consequences of the current crisis for mathematics education, the findings of this study warn the mathematics educators to implement the six principles of NTCM according to the requirements of online teaching and to make suitable instructional decisions for future online courses about teaching.

The study was conducted to investigate the Turkish PTs' views on taking a mathematics educationcourse based on the six principles of NCTM, namely equity, curriculum, teaching, learning, assessment, and technology, through online teaching at a public and a private university. Theseuniversities were located in different part of Turkey: while one of them was in the center of the country, the other was in a more rural area. The PTs in those universities differed according to the frequency of access to the Internet, the device on which online lessons are followed, having a personal computer, or having enough Internet quota to follow the online lessons.

PTstaking the mathematics education course remotely adopted either positive and/or negative reactions towards online teaching mandated by COVID-19. While most of the PTs at both universities were not satisfied with taking this course through online teaching, there were many views reflecting satisfaction. In the following, discussions on and suggestions for applying each principle of school mathematics in the context of the mathematics educationcourses were presented in order to overcome the obstacles that prevented satisfaction from online teaching and also in order to highlight the points of satisfaction. 
According to Erkut (2020), an important issue that emerged out this process was the problem of the classical separation of distance education from face-to-face education entirely in Turkey. Online teaching during COVID-19 revealed that distance education had been necessarily perceived and implemented differently than it meant through various applications and tools (e.g., recording a lesson, uploading course materials, virtual classrooms, online materials, or students as passive learners) during the pandemic. Hence, the complete separation between face-to-face and distance education in terms of the learning principle has lost its initial comprehension, and the gap between them is getting narrower through online teaching. Therefore, considering that there may be urgent, global, or local situations that will prevent face-to-face teaching again in the future, online teaching is required to be considered by the instructors from the lens of the NCTM school mathematics principles to provide a better learning environment to the PTs. In fact, the results of the present study confirmed that not only did the students learn in face-to-face classroom environments where they were physically present together, but they also achieved learning in virtual classroom environments as in online teaching.

The learning principle refers to an environment where the students' meaningful mathematics learning is achieved, and the instructors are primarily responsible for providing it (NCTM, 2000). In the online teaching process caused by the pandemic, the PTs continued learning mathematical concepts through synchronous teaching on online platforms. In terms of the effectiveness of the online learning environment, it can be claimed that the time spent for preparations to access to the course environment such as transportation is reduced (Davis et al., 2019) and the use of online materials is more common. However, regardless of the difference between the types of the university, most frequently emphasized challenges of digitally mediated learning were related to the question as to the ineffective learning and the learning environment. In line with this, some of the PTs emphasized they were learning effectively in the conventional face-to-face classroom environment. The reason for this situation might arouse from the decrease in PTs motivation due to the lack of face-to-face interaction (Yolcu, 2015). In addition to this, the PTs also emphasized that the lack of practice through concrete materials and lack of constructing knowledge were barriers of the PTs' meaningful mathematical learning. In order to accomplish the learning principle and to overcome the challenges of ineffective learning and lack of practice through concrete materials, Johnson and Aragon (2003) offered some instructional principles for designing online mathematics courses. To them, effective online learning environments could be created depending on the harmony of the following seven instructional principles: "address individual differences, motivate the student, avoid information overload, create a real-life context, encourage social interaction, provide hands-on activities, and encourage student reflection" (p. 34). Designing a course through online teaching requires being attentive to many dimensions such as the role of the students (listener, active problem solver, participant of a group work etc.) and the role of the instructors (providing feedback, explaining the content, or facilitator of a discussion etc.) (Erkut, 2020). In this unprecedented instant transition period from face-to-face to online teaching, there was insufficient time to reconsider these dimensions and make any preparation or adjustment. Considering the online teaching process that suddenly has broken into our lives, it can be said that instructors terribly need an adequate time period to apply such instructional principles as underscored in the related literature (Aristovnik et al., 2020).

The COVID-19 pandemic may last for more years, or similar situations may arise again, and to design an effective online teaching course enabling effective learning light of the instructional principles may take months (Erkut, 2020). Effective teaching and learning can be achieved with a well-designed online environment. Interactive classroom environments can be provided to the learners through online teaching, but it requires the systematic applied conditions in particular contexts. In any case, instructional principles specific to mathematics teaching can be determined by taking the results of this study into account. The views of the PTs addressing the implementation of principles for school mathematics could be a part of the principles. Faculty members who want to apply the NCTM principles in mathematics education course implemented in online teaching should consider the foundational status of technology as embedded in these principles. In corollary to this, applying the NCTM principles should be discussed with instructors' technological pedagogical content knowledge, which refers to technological knowledge and its application with an appropriate pedagogy to teach mathematics. The results of this study showed that, in general, the PTs had remarkably a positive reaction towards the integration of technology into learning (for PBU students) or teaching (for PRU students) even in this urgent process.

Considering that it was the first online teaching experience for most of the lecturers and the PTs, it can be concluded that either the teaching methods should be reconsidered in subsequent courses or the shift to online teaching needs more time for the stakeholders to get used to. Ferdig et al. (2020) revealed the innovations, changes, and experiences in education during the COVID19 pandemic and presented various applications to set an example for educators in this ongoing process. Likewise, the results of this study were reported in detail so that the mathematics educators could benefit from the challenges and advantages presented in this study to mitigate the effects aroused by the pandemic.

As displayed in Table 1 and Table 2, the result of the study indicated that the common challenge to the implementation of the teaching principle and learning principle were the lack of practice through concrete materials. Accordingly, the PTs need to keep practicing through concrete material as well as they want to be exposed to making practice through concrete materials as a teaching method by the teacher. Concrete materials helped the PTs understand the mathematical concepts and were an instructional way for the instructors to teach the mathematical concepts through the materials in face-to-face education before the online teaching. However, it was not feasible for PTs to own these materials and not to be actively involved in learning mathematics with the concrete materials in this digitally mediated teaching in virtual classroom platforms. So, this handicap can be overcome by integrating virtual manipulatives into mathematics education courses since some of the PTs referred to the use of various mathematics manipulative available online. The Internet provides a plenty of e-resourcesfor online education (Kalelioğlu et al., 2016). In order to improve the quality of effective online learning environments, we, the researchers as instructors, thought we could live up to the expectations of keeping teaching through the concrete materials with the help of virtual manipulatives. Considering the potential of virtual manipulatives for being "more accessible at home than the concrete ones" (Hunt et al., 2011, p. 3) for both instructors and PTs, they were consideredto be acceptable substitutes for concrete hands- 
on material (Durmuş \& Karakırık, 2006). However, it should not be forgotten that this situation basically requires pre-service teachers to have a computer, phone, or tablet. Moreover, virtual material integration does not necessarily guarantee effective online learning environments (Hunt et al., 2011) but, nonetheless, they have a potential to helplearners make practices out of class hours and learn actively by engaging with them (Moyer et al., 2002). They can also be used not only to reinforce conceptual understanding, but also to evaluate students, encourage them to work together, or reflect on their own learning (Clements \& McMillen, 1996). What is more, online materials and e-resources such as the OpenLearn website (Daniel, 2020) can serve well as a supplementary for hands-on materials to ward offthis challenge. In this case, lecturers should design course contents with sound pedagogy and technologies through online materials and activities. This situation will inevitably stipulate that instructors should be competent about the virtual materials of mathematics education.

As mathematics educators, we aim to prepare an effective mathematics teaching environment that "requires understanding what students know and need to learn and then challenging and supporting them to learn it well" (NCTM, 2000, p. 11). In this urgent process, we still continue to have this particular aim yet the results of the study showed that most of the students in two groups were dissatisfied with or undecided about the adaptation of the teaching principle into online teaching. From this point of view, it can be claimed that the learners' dissatisfaction with online teaching was not an unexpected result as it was hugely different from conventional teaching methods. However, the prominent status of technology principle and its link to teaching principle is important in criticizing the instructional approach adapted by the instructors. Applying the technology principle in mathematics classrooms originally dwells on utilizing technology in teaching mathematics for students' learning (NCTM, 2000). The PTs constantly referred to the technology principle while discussing the other principles. Therefore, the technology principle has found out to be a principle in which the other principles were organized and applied according to it. The early conceptualization of technology principle mainly focused on integrating technological tools into learning and teaching processes in mathematics course. In this unprecedented pandemic process, as the views of the PTs demonstrated, not only the teaching and the learning principles but also the assessment and the equity principles should be discussed and revisited according to the technology principle. Although technology principle was regarded as a choice to integrate technology into teaching and learning processes before the pandemic, it is now an indispensable part of the process, and it functions as the central organizing principle in this digitally-mediated teaching.

The closure of schools brought about social and economic problems in different ways on a worldwide scale such as digital learning or access to the Internet (Aristovnik et al., 2020; Erkut, 2020). Prior studies have noted that socio-economic parameters could cause inequalities in remote teaching (Li et al., 2014). The current study drew attention to suchparameters asthe frequency of the Internet access, enough Internet quotas to follow the courses, and technological tools necessary for online courses. The survey results addressing the equity principle demonstrated that somePTs did not have everyday Internet access, enough Internet quotas to follow the courses, and technological tools necessary for online courses. This result supports Karadağ and Yücel (2020)'s study that only $63 \%$ of the undergraduate students in Turkey have the Internet connection and one-third of the students do not have a computer or tablet at all. Similarly, Yılmaz-ince et al. (2020) found out that university students' views about online teaching in Turkey were mainly shaped in accordance with their access to computers and the Internet. Thus, access to technology has become an essential dimension of educational equity (NCTM, 2000). The current study also found that both cases commonly addressed the equity principle integrated into the technology principle, highlighting the lack of individual resources, including the Internet access and necessary electronic devices as represented in Table 3. In a corollary to this, some PTs were falling behind their peers, and they needed help on the issue of having better support of resources. In this study, it is not quite clear whether the reason for the divergence of PTs' views of satisfaction is due to equity or not. So, we can just suggest that the lack of opportunities related to the equity need to be remediedas soon as possible for effective learning. To meet these demands, for instance, public institutions or private companies can be called for help. The internet quota problems could be solved by individual or enterprise agreements (e.g., METU students' Internet is on me!, aka. ODTÜ'lünün İnterneti de Benden! in Turkish) to supply their needs. In this context, $6 \mathrm{~GB}$ quota given by CoHE for supporting online teaching was essential (Karadağ \& Yücel, 2020); however, considering the number of courses the students attend, it may not be sufficient. It is essential that the students are given the opportunity to acquire a future-dated and rather inexpensive computer and tablet (Karadağ \& Yücel, 2020). Contrary to what is expected, very few students ( $11 \%$ of PBU and $2 \%$ of PRU) mentioned these inequalities as the reason for their dissatisfaction with online teaching. However, most PTs in PBU faced inequalities in terms of their resources regarding computers (65\% of the PTs did not have personal computers), everyday access ( $37 \%$ of the PTs had restrictions of everyday access), and the Internet quota ( $48 \%$ of the PTs did not have enough quota). In other words, the PTs at PBU did not represent common views over the digital divide regarding the resources. The underlying reason might be hidden in the context of the courses because, due to the pandemic and transition to the online teaching, the requirements of the course were changed and updated in a very short time span by taking the socioeconomic factors of the students into account. The students were not required to fulfill many things they were obliged before the pandemic such as to attend courses physically, to participate in the courses actively, to do assignments on computers, or to be prepared before the class. Therefore, it led to a much more flexible process regarding these requirements compared to faceto-face teaching. In this sense, the instructors adjusted the expectations from PTs concerning the equity of technology principle, and the PTs might not feel themselves in a digital divide. Another explanation may be the fact that having a smartphone facilitated the process. The PTs who did not have computers or tablets were able to go through the learning process only by smartphones within the context of considerably reduced expectations mentioned earlier. With this study, it was revealed that potential facilitators of applying this principle in such a process included the instructors' flexible expectations from undergraduate students and their use of smartphones.

Assessment is an essential indicator of whether the learning objectives are accomplished (NCTM, 2000). In mathematics education, the students' knowledge of mathematics, process skills, and attitudes towards mathematics constitute the main focuses of evaluation (Van de Walle et al., 2013). The sudden shift from regular to remote teaching due to the pandemic pushed 
the instructors to apply the assessment principle remotely for the first time before the midterm exams in Turkey. The instructors' applications of this principle were entirely left to the initiatives of the universities. The present study revealed that both of the instructors used formal assessment methods in the form of online exams and assignments in the private university. In contrast, at the public university, it was conducted through homework assignments. As it can be seen, there was a considerable effect of the pandemic on the measurement and assessment process in Turkey as well. In a similar line of thought, in a study focusing on the situation in Portuguese education system during the pandemic, it was indicated that pedagogical and technical challenges were added to issues about assessment in online teaching (Flores \& Gago, 2020). Portuguese instructors stated that student participation in informal assessments showed a decreasing trend during the pandemic. Congruent with this, unless the active participation of students is officially required, which is not applicable in such a process, it will not be possible to expect in-class assessment to contribute to students' learning in formative or informative assessment. What is more, longer-term assignments seem to be a possible way to give feedback for the lecturers. Providing immediate and elaborative feedback can solve the students' problems attending online teaching (Johnson \& Aragon, 2003). However, it should not be disregarded that assignments to be completed in a short time will be challenging in terms of giving feedback.

During the pandemic, online teaching produced dramatic challenges for the informal assessment through classroom interaction and formal assessment through the exams with high validity and reliability and without technical problems. Previously done informal and formal assessments of students have completely turned into a formal assessment. Since the students were not officially required to participate in the courses, the assessment principle had to be addressed solely through formal assessment. Therefore, these considerations caused an increase in the number of assignments for every course as indicated in the PTs' statements in PRU. Similar to the other courses, the number of assignments was increased in mathematics education courses. Hence, the utilization of various types of assessment in online teaching is a crucial suggestion in the present study, confirming what Johnson and Aragon (2003) put, this sudden process left lecturers no choice but to increase the percentage of the assignments in the grading. Contrary to expectations, the current study found that few PTs in PRU had concerns about the assessment addressing "the time problems about completing assignments". It was found that the lack of students' technological knowledge was an obstacle affecting the student's progress in assessment. Related to lack of technological knowledge, a PT at PBU pointed out that he had problems with uploading the assignments and the type of format they would use. The reason why just a few students referred to this point was probably derived from the fact that there was a flexible assessment process gone through only using assignments.

Designed for the teacher educators to pay more attention to the online lessons specific to mathematics teaching during COVID19 , the current study revealed that conventional school-based education still maintains its importance for the PTs, and there is an urgent need for improvement in distance education, especially for teacher practices regarding the teaching and learning principle. However, in today's world of sudden happenings and swiftly-advancing digital possibilities, nothing will remain the same for faculty members and students undergoingonline activities. It seems to be an undeniable fact that distance education will occupy an important part of the life of the students in the following semesters more.

Author contributions: All authors have sufficiently contributed to the study, and agreed with the results and conclusions.

Funding: No funding source is reported for this study.

Declaration of interest: No conflict of interest is declared by authors.

\section{REFERENCES}

Aristovnik, A., Keržič, D., Ravšelj, D., Tomaževič, N., \& Umek, L. (2020). Impacts of the COVID-19 pandemic on life of higher education students: A global perspective. Sustainability, 12(8438), 1-34. https://doi.org/10.3390/su12208438

Bakker, A., Wagner, D. (2020). Pandemic: lessons for today and tomorrow? Educational Studies in Mathematics, $104,1-4$. https://doi.org/10.1007/s10649-020-09946-3

Baran, E., Correia, A. P., \& Thompson, A. (2011). Transforming online teaching practice: Critical analysis of the literature on the roles and competencies of online teachers. Distance Education, 32(3), 421-439. https://doi.org/10.1080/01587919.2011.610293

Caliskan, S., Suzek, S., \& Ozcan, D. (2017). Determining student satisfaction in distance education courses. Procedia Computer Science, 120, 529-538. https://doi.org/10.1016/j.procs.2017.11.275

Clements, D. H., \& McMillen, S. (1996). Rethinking concrete manipulatives. Teaching Children Mathematics, 2(5), $270-279$.

Council of Higher Education [CoHE] (2020a). Koronavirüs (Covid-19) bilgilendirme notu: 1 [Coronavirus (Covid-19) information note: 1]. https://www.yok.gov.tr/Sayfalar/Haberler/2020/coronavirus_bilgilendirme_1.aspx

Council of Higher Education [CoHE] (2020b). YÖK başkanı Saraç üniversitelerde verilecek olan uzaktan eğitime ilişkin açıklama yaptı [President of YÖK Saraç made a statement on distance education to be given at universities]. https://www.yok.gov.tr/Sayfalar/Haberler/2020/universitelerde-uygulanacak-uzaktan-egitime-iliskin-aciklama.aspx

Council of Higher Education [CoHE] (2020c). CoHE gave information about the regulations for final exams in the universities. https://www.yok.gov.tr/Sayfalar/Haberler/2020/universitelerde-dijital-sinavlarin-temel-ilkeleri.aspx

Daniel, J. (2020). Education and the COVID-19 pandemic. Prospects, 49(1), 91-96. https://doi.org/10.1007/s11125-020-09464-3

Davis, N. L., Gough, M., \& Taylor, L. L. (2019). Online teaching: advantages, obstacles and tools for getting it right. Journal of Teaching in Travel \& Tourism, 19(3), 256-263. https://doi.org/10.1080/15313220.2019.1612313 
Devlin, M., \& McKay, J. (2016). Teaching students using technology: Facilitating success for students from low socioeconomic status backgrounds in Australian universities. Australasian Journal of Educational Technology, 32(1), 92-106. https://doi.org/10.14742/ajet.2053

Durmuş, S., \& Karakırık, E. (2006). Virtual manipulatives in mathematics education: A theoretical framework. The Turkish Online Journal of Educational Technology, 5(1), 117-123.

Dutta, S., \& Smita, M. K. (2020). The impact of COVID-19 pandemic on tertiary education in Bangladesh: Students' perspectives. Open Journal of Social Sciences, 8, 53-68. https://doi.org/10.4236/jss.2020.89004

Eren, E. (2020). Yeni tip koronavirüs'ün türk eğitim politikaları uygulamalarına etkisi: Milli Eğitim Bakanlığının ve Yükseköğretim Kurulu'nun yeni düzenlemeleri [The effect of the new type of coronavirus on Turkish education policy practices: New regulations of the Ministry of National Education and the Council of Higher Education]. Yükseköğretim Dergisi, 10(2), 153-162. https://doi.org/10.2399/yod.20.716645

Erkut, E. (2020). Covid-19 sonrası Yükseköğretim [Higher Education after Covid-19].Yükseköğretim Dergisi, 10(2), 125-133. https://doi.org/10.2399/yod.20.002

Ferdig, R. E., Baumgartner, E., Hartshorne, R., Kaplan-Rakowski, R., \& Mouza, C. (Eds). (2020). Teaching, Technology, and Teacher Education During the COVID-19 Pandemic: Stories from the Field. Association for the Advancement of Computing in Education (AACE).

Filiz, S. B., \& Ergan, S. N. (2020). Illkokul matematik dersi öğretim programının beş süreç standardına göre değerlendirilmesi [Evaluation of primary school mathematics curriculum according to five process standards]. Sosyal Bilimler Arastirmalari Dergisi, 10(2), 464-477.

Flores, A. M., \& Gago, M. (2020). Teacher education in times of COVID-19 pandemic in Portugal: national, institutional and pedagogical responses. Journal of Education for Teaching, 46(4), 507-516. https://doi.org/10.1080/02607476.2020.1799709

Fraenkel, J. R., Wallen, N. E., \& Hyun, H. H. (2011). How to design and evaluate research in education (8th ed.). McGraw-Hill Companies.

Harman, C., \& Dorman, M. (1998). Enriching distance teaching and learning of undergraduate mathematics using videoconferencing and audiographics, Distance Education, 19(2), 299-318. https://doi.org/10.1080/0158791980190208

Hunt, A. W., Nipper, K. L., \& Nash, L. E (2011). Virtual vs. concrete manipulatives in mathematics teacher education: Is one type more effective than the other? Current Issues in Middle Level Education, 16(2), 1-61. https://doi.org/10.20429/gamte.2008.020103

Johnson, S. D., \& Aragon, S. R. (2003). An instructional strategy framework for online learning environments. New Directions for Adult and Continuing Education, 100, 31-43. https://doi.org/10.1002/ace.117

Kalelioğlu, F, Atan, A., \& Çetin, Ç. (2016). Sanal sınıf ortamında eğitmen ve öğrenen deneyimleri [Instructor and learner experiences in the virtual classroom environment to the five process standards of the primary school mathematics curriculum]. Mersin Üniversitesi Eğitim Fakültesi Dergisi, 12(2), 555-568. https://doi.org/10.17860/efd.34388

Karadağ, E., \& Yücel, C. (2020). Yeni tip koronavirüs pandemisi döneminde üniversitelerde uzaktan eğitim: Lisans öğrencileri kapsamında bir değerlendirme çalışması [Distance education at universities during the new type of coronavirus pandemic: An evaluation study within the scope of undergraduate students]. Yükseköğretim Dergisi, 10(2), $181-192$. https://doi.org/10.2399/yod.20.730688

Koehler, M. J., \& Mishra, P. (2005). What happens when teachers design educational technology? The development of technological pedagogical content knowledge. Journal of Educational Computing Research, 32(2), 131-152. https://doi.org/10.2190/0EW701WB-BKHL-QDYV

Lambert, S. R. (2020). Do MOOCs contribute to student equity and social inclusion? A systematic review 2014-18. Computers \& Education, 145, 103693. https://doi.org/10.1016/j.compedu.2019.103693

Li, F., Zhou, M., \& Fan, B. (2014). Can distance education increase educational equality? Evidence from the expansion of Chinese higher education. Studies in Higher Education, 39(10), 1811-1822. https://doi.org/10.1080/03075079.2013.806462

Mailizar, M., Almanthari, A., Maulina, S., \& Bruce, S. (2020). Secondary school mathematics teachers' views on e-learning implementation barriers during the COVID-19 pandemic: The Case of Indonesia. Eurasia Journal of Mathematics Science Technology Education, 16(7), em1860. https://doi.org/10.29333/ejmste/8240

Ministry of National Education [MoNE] (2018). Mathematics Education Curriculum (Primary and Middle School). Ministry of National Education Press.

Moyer, P. S., Bolyard, J. J., \& Spikell, M. A. (2002). What are virtual manipulatives? Teaching Children Mathematics, 8(6), $372-377$. https://doi.org/10.5951/TCM.8.6.0372

National Council of Teachers of Mathematics. (2000). Principles and Standards for School Mathematics. Reston, VA.

Perienen, A. (2020). Frameworks for ICT integration in mathematics education - A teacher's perspective. EURASIA Journal of Mathematics, Science and Technology Education, 16(6), em1845. https://doi.org/10.29333/ejmste/7803

Roca, J. C., Chiu, C-M., \& Martinez, F. J. (2006). Understanding e-learning continuance intention: An extension of the Technology Acceptance Model. International Journal of Human- Computer Studies, 64, 683-696. https://doi.org/10.1016/j.ijhcs.2006.01.003

Rose, R., \& Blomeyer, R. (2007). Access and equity in online classes and virtual schools. International Association for K-12 Online Learning. https://aurora-institute.org/we-content/uploads/iNACOL_AccessEquity_2007.pdf 
Umay, A., Çıkla, O. A., \& Duatepe, A. (2006). Matematik dersi 1.-5.sınıf öğretim programının NCTM prensip ve standartlarına gore incelenmesi [Examination of mathematics lesson 1st-5th grade curriculum according to NCTM principles and standards]. Hacettepe Üniversitesi Eğitim Fakültesi Dergisi, 31, 198-211.

Üredi, L., \& Ulum, H. (2019). An investigation primary school mathematics curriculum by principles for school mathematics. Necatibey Faculty of Education Electronic Journal of Science \& Mathematics Education, 13(2), 789-806.

Van De Walle, J. A., Karp, K. S., \& Bay-Williams J. M. (2013). Elementary and middle school mathematics: Teaching developmentally (8th ed.). Pearson.

World Health Organization [WHO]. (2020). WHO characterizes the COVID-19 as a pandemic. https://www.who.int/emergencies/diseases/novel-coronavirus-2019/events-as-they-happen

Yılmaz-İnce, E., Kabul, A., \& Diler, İ. (2020). Distance education in higher education in the COVID-19 pandemic process: A case of Isparta Applied Sciences University. International Journal of Technology in Education and Science (IJTES), 4(4), 343-351. https://doi.org/10.46328/ijtes.v4i4.112

Yin, R. (2003). Case study research: Design and methods ( ${ }^{\text {rd }}$ ed.). Sage Publications.

Yolcu, H. H. (2015). Harmanlanmış (Karma) öğrenme ve uygulama esasları [Fundamentals of blended learning and practice]. The Journal of Academic Social Science Studies, 33, 255-260. https://doi.org/10.9761/JASSS2767

Yolcu, H.H. (2020). Sınıf öğretmeni adaylarının uzaktan eğitim deneyimleri [Distance education experiences of primary school teacher candidates]. Açıköğretim Uygulamaları ve Araştırmaları Dergisi (AUAd), 6(4), 237-250. 